Research Article

\title{
Study on Gas Control Methods Optimization for Mining Safety
}

\author{
Liwen He $\mathbb{D}^{1}{ }^{1}$ Yingcheng Dai, ${ }^{1}$ Sheng Xue $\mathbb{D}^{2,3}$ Chunshan Zheng, ${ }^{2,3}$ \\ Baiqing Han, ${ }^{4}$ and Xin Guo $\mathbb{D}^{2,3}$ \\ ${ }^{1}$ College of Environment and Resources, Xiangtan University, Xiangtan 411100, China \\ ${ }^{2}$ Institute of Energy, Hefei Comprehensive National Science Center, Hefei 230031, China \\ ${ }^{3}$ School of Safety Science and Engineering, Anhui University of Science and Technology, Huainan 232001, China \\ ${ }^{4}$ China National Coal Xinji Group Corporation, Huainan 232001, China
}

Correspondence should be addressed to Sheng Xue; sheng.xue@aust.edu.cn

Received 29 July 2021; Revised 27 August 2021; Accepted 16 November 2021; Published 21 December 2021

Academic Editor: Peng Liu

Copyright $\odot 2021$ Liwen He et al. This is an open access article distributed under the Creative Commons Attribution License, which permits unrestricted use, distribution, and reproduction in any medium, provided the original work is properly cited.

\begin{abstract}
Effective gas control is of significance for safe efficient coal mining in Haizi Coal Mine and other mines with similar geological conditions. This study concentrates on gas control theories and techniques in multiple coal seams of Haizi Coal Mine (No. 7, No. 8, No. 9, and No. 10 coal seam from top to bottom). To minimize risk of high gas emission and outburst hazard, No. 10 seam was mined first as a protective seam prior to the mining of its overlying outburst-prone No. 7, No. 8, and No. 9 seam. Four gas drainage measures were determined for gas control, including cross-measure boreholes into overlying coal seams, surface goaf wells, roof boreholes, and roof gas drainage roadway. These gas control measures, if implemented through entire coal seam extraction, would be possibly uneconomic. An investigation was undertaken to analyze effects of those four measures on gas emission, methane concentration, and gas drainage quantity in No. 21024 mining panel of No. 10 seam. Results indicate that the highly expensive gas drainage measure of a roof roadway has poor drainage performance and could be effectively replaced by roof boreholes. When adopting the optimized combination of gas drainage measures, drainage efficiency of No. 7 seam, No. 8 seam, and No. 9 seam could reach $58.64 \%$ and decrease gas pressure to be below $0.74 \mathrm{MPa}$. Outcomes of this study could provide beneficial guidance not only for gas drainage design optimization in Haizi Coal Mine but also for other multiple-seam mines with similar mining and geological conditions, for increasing gas drainage efficiency and guaranteeing mining safety.
\end{abstract}

\section{Introduction}

Due to the specific conditions of energy demand in Chinese economic development, coal has been and will continue to be the dominant energy resource in China. Hence, safe production and sustainable development of coal industry are of significance. However, coal mine safety remains to be a key obstacle in mining activities. According to statistics, 3985 gas incidents occurred in Chinese coal mines in the period from 2001 to 2013 when coal industry developed rapidly [1]. Therefore, preventing the occurrence of gas disasters is of great necessity.

Most coal mines in China have multiple coal seams. To minimize the risk of high gas emission and coal and gas outburst, a less outburst-prone seam is often mined first as a protective seam prior to the mining of its overlying or underlying seams. Meanwhile, these relieved overlying or underlying seams are called protected seam as these seams experience substantial stress relief and permeability enhancement which both could help preventing mining hazards [2]. This protective seam mining method has been widely applied and delivered large amount of benefits on guaranteeing mining safety $[3,4]$. Gas drainage measures are always adopted in combination with this method. Popular gas drainage measures include surface gas wells, underground gas boreholes, and tunnels or combination of the above. Starting in the 1970s, Chinese coal mines adopted the protective mining method with various gas drainage measures depending on localized geological and mining conditions, e.g., cross-measure boreholes were used to drain gas from relieved protected seams in No. 4 Mine of Yangquan Coal Group in Shanxi Province, Wudanggou Coal Mine in 
Inner Mongolia, and Dayong Coal Mine in Guizhou Province [5]. In Yutianbao Coal Mine of Nantong Mining Area and Xieqiao Coal Mine in Huainan City, the crossmeasure borehole method in the intake airflow lane of mining panel is also adopted, in which the drilling-site construction is convenient and the maintenance time and workload of lane do not increase [6-11]. Moxinpo Coal Mine in Chongqing City and Luling Coal Mine in Anhui Province chose to drill drainage boreholes in the roadway located outside protective layer. This method is widely used for panel in coal seams of various dip angle and mining methods $[12,13]$.

Over the years, the protective mining method combined with various gas drainage measures has been studied and applied in various coal seam conditions [14-19]. In general, taking more comprehensive gas drainage measures could lead to better gas control. However, implementation of comprehensive gas drainage measures is quite expensive, particularly in current weak coal market. It is therefore important to optimize these gas drainage measures without compromising gas control effectiveness. Taking Haizi Coal Mine as an example, this study discusses on-site investigation results of optimization of gas drainage measures combined with the multiple-seam protective mining method, for providing references on conducting safe efficient gas drainage and coal mining in large amount of coal mines similar to Haizi Coal Mine.

\section{Site Conditions}

Haizi Coal Mine of Huaibei Mining Company is located about $40 \mathrm{~km}$ north of Huaibei City, Anhui Province, China (Figure 1). This mine adjoins another coal mine named Linhuan in the southeast (separated by a Fault) and is bounded by the Daliujia Fault in the west. Recoverable mining area is about $11 \mathrm{~km}$ long and $2.6 \mathrm{~km}$ wide, covering an area of approximately $26.7 \mathrm{~km}^{2}$.

There are 10 coal seams in the mining area, numbered from top to bottom as No. 1 to No. 10 seam. Generalized stratigraphic column is shown in Figure 2. Four seams including No. 7 seam, No. 8 seam, No. 9 seam, and No. 10 seam are mainly extracted. Gas pressure of those four coal seams is 1.6 $\mathrm{MPa}, 0.8 \mathrm{MPa}, 0.85 \mathrm{MPa}$, and $0.6 \mathrm{MPa}$, respectively. Gas contents of them are $12 \mathrm{~m}^{3} / \mathrm{t}, 8.7 \mathrm{~m}^{3} / \mathrm{t}, 9 \mathrm{~m}^{3} / \mathrm{t}$, and $5 \mathrm{~m}^{3} / \mathrm{t}$, respectively. The thickness of those four coal seams is $0.5 \mathrm{~m}$, $1.1 \mathrm{~m}, 0.7 \mathrm{~m}$, and $9 \mathrm{~m}$, respectively.

Coal mine risk assessment shows that except for No. 10 seam, the other three extraction seams (No. 7 seam, No. 8 seam, and No. 9 seam) are both outburst-prone. No. 10 seam belongs to the igneous intrusion area, and it does not have outburst-prone. Therefore, in this multiple-seam mining, No. 10 seam is mined first as the protective seam, for decreasing risk of outburst and high gas emission during mining activities of its adjacent overlying seams.

This study concentrates on the No. 21024 panel of No. 10 seam. No. 21024 panel is located in the east wing of No. 2 102 Mining Area as shown in Figure 3. Its upper border is the goaf of No. 21022 panel, while its lower border is the planned No. 21026 panel. The eastern border is safety coal pillar of No. 2102 Mining Area, and the western border is nonrecoverable area of No. 2102 Mining Area. Its elevation is between $-593 \mathrm{~m}$ and $-657 \mathrm{~m}$. The panel is $550 \mathrm{~m}$ long and $185 \mathrm{~m}$ wide with an area of around $101750 \mathrm{~m}^{2}$. Thickness of the coal seam is $2.7 \mathrm{~m}$ with an average dip angle of $20^{\circ}$ in No. 21024 panel.

\section{Gas Drainage Design of No. 21024 Panel}

3.1. Design Principle. Protective seam mining is one of the most economic and effective method in mitigating coal and gas outburst risk of multiple coal seam group. Mining the protective No. 10 seam in Haizi Coal Mine will significantly affect the stress and gas conditions in protected overlying seams of No. 7, No. 8, and No. 9. As the protective seam being mined, three roof zones in vertical direction will be formed, namely, caved zone, fractured zone, and subsidence zone $[20,21]$. Stress in the protected seams will decrease, fractures generate, and permeability increases, and finally gas desorbs and pressure drops. As a result, coal and gas outburst risk in protected seams is reduced, as shown in Figure $4[19,22,23]$.

It should be noted that there is a hard igneous rock layer in the overlying strata of No.7 seam. This will prolong the subsiding time of overlying strata and the fracture closure time in the fractured zone. This extra time is good for gas drainage if drainage boreholes are in place prior to the extraction of protective No. 10 seam.

3.2. Gas Drainage Design. Effective gas drainage is essential to Haizi Coal Mine as a complex outburst-prone mine. Four gas drainage measures are initially designed for No. 21024 panel, including cross-measure boreholes into the protected seams, surface goaf wells, roof boreholes, and a roof gas drainage roadway. These methods are popularly used in coal mines. Detailed design of these measures is described below.

Cross-measure boreholes serve two purposes in Haizi Coal Mine. One is preventing excessive gas from adjacent seams into No. 21024 panel. Another one is draining gas released from overlying protected seams to reduce or eliminate the outburst risk. Figure 5 illustrates principle of gas emission in protected coal seams and gas extraction methods using cross-measure boreholes.

Some of the boreholes are designed to only pass through No. 7 seam and No. 8 seam by $0.5 \mathrm{~m}$, while the others will be drilled past No. 9 seam by $0.5 \mathrm{~m}$. As these overlying seams are soft and of low permeability, boreholes with $94 \mathrm{~mm}$ diameter are adopted to minimize risk of borehole collapse and closure. Bottom of the boreholes is spaced $10 \mathrm{~m}$. A cross section of cross-measure boreholes is shown in Figure 6.

Surface wells are frequently used to capture goaf gas. Typically, with the advance of a panel in a protective seam, "three horizontal zones" are also formed in overlying strata, namely, intact zone, separation zone, and recompaction zone (Figure 7). With the development of working face, bending subsidence zone also goes with it. In the development process, the overlying protected coal seam in bending subsidence zone will be broken, permeability 


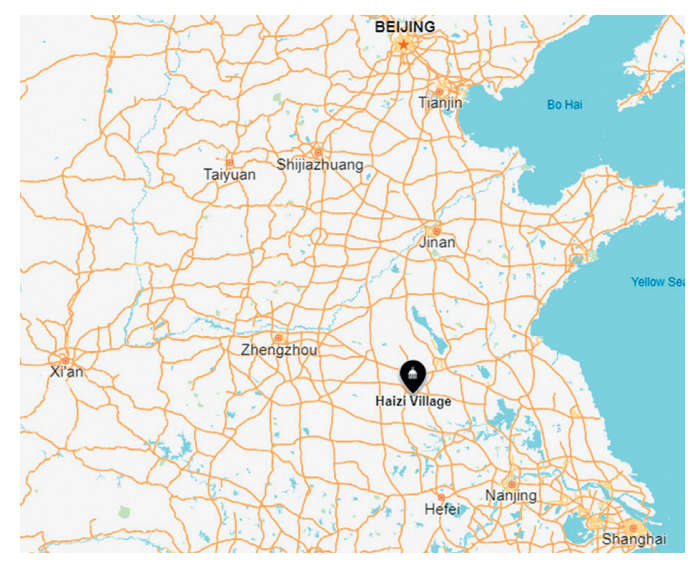

(a)

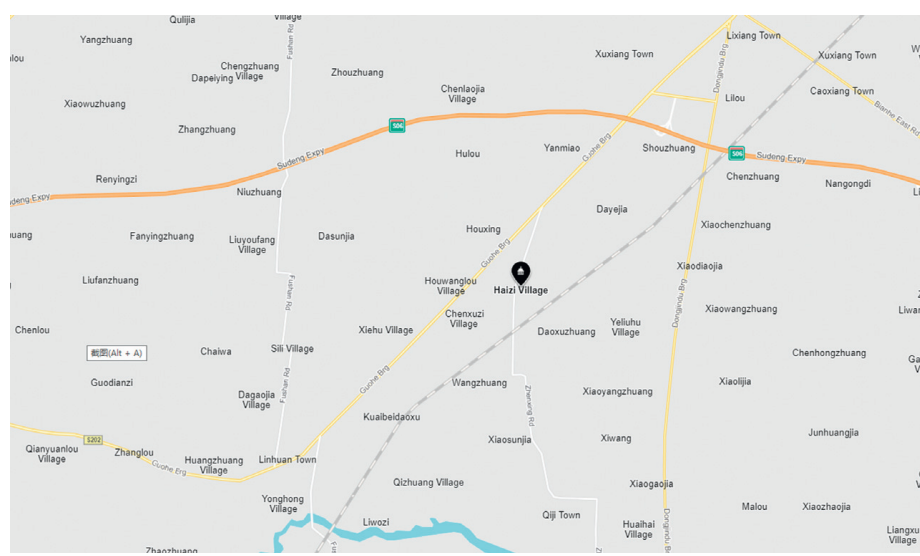

(b)

Figure 1: Location of Haizi Coal Mine.

experiences increase, and a large amount of gas emits out. Fracture network becomes flow channels of gas, and gas could be drained by surface wells.

Each of those two wells consists of four sections, as shown in Figure 9.

(1) Surface Pipe. Use a $\phi 311 \mathrm{~mm}$ bit to drill the well. Cement it with a $\phi 245 * 10 \mathrm{~mm}$ casing to prevent water in quaternary aquifer from getting into the underground from new strata to bedrock.

(2) Bedrock Pipe. Use a $\phi 216 \mathrm{~mm}$ bit to drill well to the position 2-5 $\mathrm{m}$ above No. 7 seam roof and cement it.

(3) Perforated Pipe. Adopt a $\phi 152 \mathrm{~mm}$ bit to drill well through No. 7 seam, No. 8 seam, and No. 9 seam to 4-5 $\mathrm{m}$ above the top of No. 10 seam. Put a $\phi 139.7^{*} 9.17 \mathrm{~mm}$ casing in this section. Its purpose is to prevent well from collapsing in No. 8 seam and No. 9 seam under the influence of No. 10 seam mining. Meanwhile, the well is gas passage from No. 7 seam, No. 8 seam, and No. 9 seam and goaf of No. 10 seam.

(4) Wooden Plug. Finally, use a $\phi 94 \mathrm{~mm}$ bit to drill the well to No. 10 seam floor and block it up with a $\phi 95 \mathrm{~mm}$ wooden plug. Its purpose is to prevent water flowing into mining panel when the panel passes well.

Roof boreholes are drilled into the roof of protective seam from ventilation roadway of mining area. The boreholes are under suction pressure and used to capture roof gas which may otherwise flow into longwall mining face.

Highly located drilling site is placed in No. 21024 ventilation roadway and is constructed in every $80-110$ meters. There is $2.5 \mathrm{~m}$ rock pillar between floor of drilling sit and coal seam roof. A $108 \mathrm{~mm}$ diameter bit is used to drill borehole up to $6 \mathrm{~m}$, and then a $89 \mathrm{~mm}$ diameter bit is adopted to drill the other borehole section. Borehole depth is drilling field spacing plus 40 meters, and borehole position is at 3.5 meters from coal seam roof. It is determined that bottom position of borehole is about 30 meters from coal seam roof according to drainage situation in Haizi Coal
Mine. Five boreholes are constructed in each drilling site, as shown in Figure 10.

A special roof roadway parallel with panel gateroads is designed in the fractured zone of roof of protective seam. This roadway is used to capture goaf gas. In the initial stage of panel mining from its starting position, some boreholes are required to be drilled downward from the roadway into panel caving zone to obtain effective gas drainage as at this time the fractured zone of roof may not extend to roadway area. The best position of roadway for effective gas drainage is in the range of about $20 \mathrm{~m}$ in roof of protective seam and $20 \mathrm{~m}$ inside the panel gateroad in Haizi Coal Mine. One end of the roadway is $50 \mathrm{~m}$ inside the panel starting line, and a total of 9 boreholes of $94 \mathrm{~mm}$ in diameter are designed at the end of roadway. Those boreholes are drilled downward into protective No. 10 seam and are arranged in fan pattern, as shown in Figure 11.

\section{Gas Drainage Design Optimization in No. 2 1024 Mining Panel}

During mining process of No. 21024 panel, investigations are undertaken to study effects of different gas drainage measures on gas emission, methane concentration at working face, and gas drainage quantity. Four different combinations of gas drainage measures are adopted. In Case 1, all of above four gas control measures are implemented; in Case 2, the roof boreholes are not used while the other three measures being implemented; in Case 3, the roof gas tunnel and accompanying boreholes are not adopted when the other three measures are in operations, and in Case 4, the cross-measure boreholes are closed and the other three measures are implemented. The panel gas emission, methane concentration at working face, and gas drainage quantity of each drainage case are monitored by using gas sensor and orifice plate flowmeter. According to the daily data report of coalmine, variations of these monitored parameters are shown in Figures 12-15.

As indicated in Figures 12-15, for the case roof boreholes being not adopted, the panel relative and absolute gas emission 


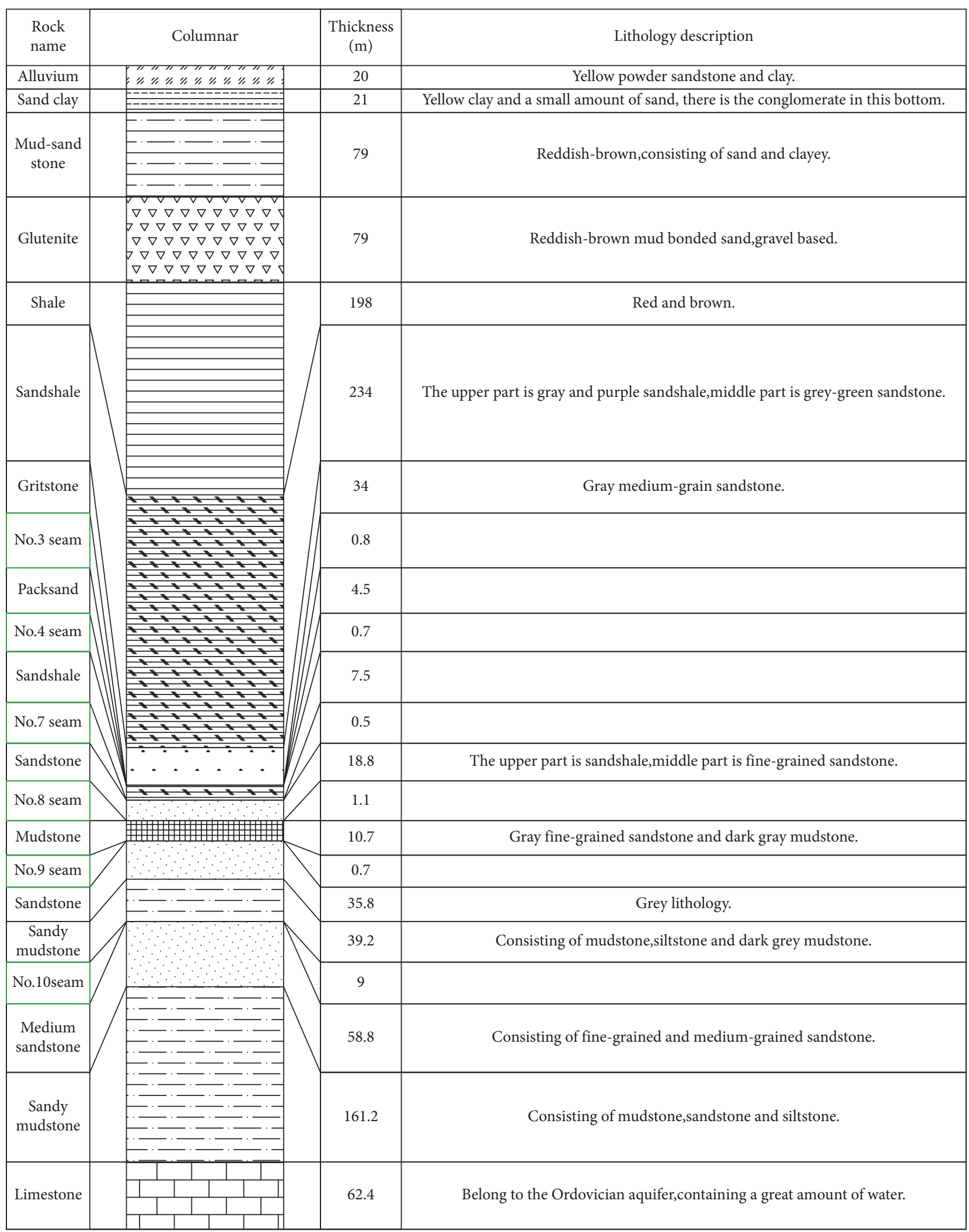

Figure 2: Generalized stratigraphic column of Haizi Coal Mine.

increases substantially before decreasing slowly. Meanwhile, gas drainage quantity in surface wells and cross-measure boreholes increases. The growth of gas drainage quantity from roof gas drainage tunnel and accompanying boreholes also slightly becomes bigger. However, there are no significant changes being observed in methane concentration. 


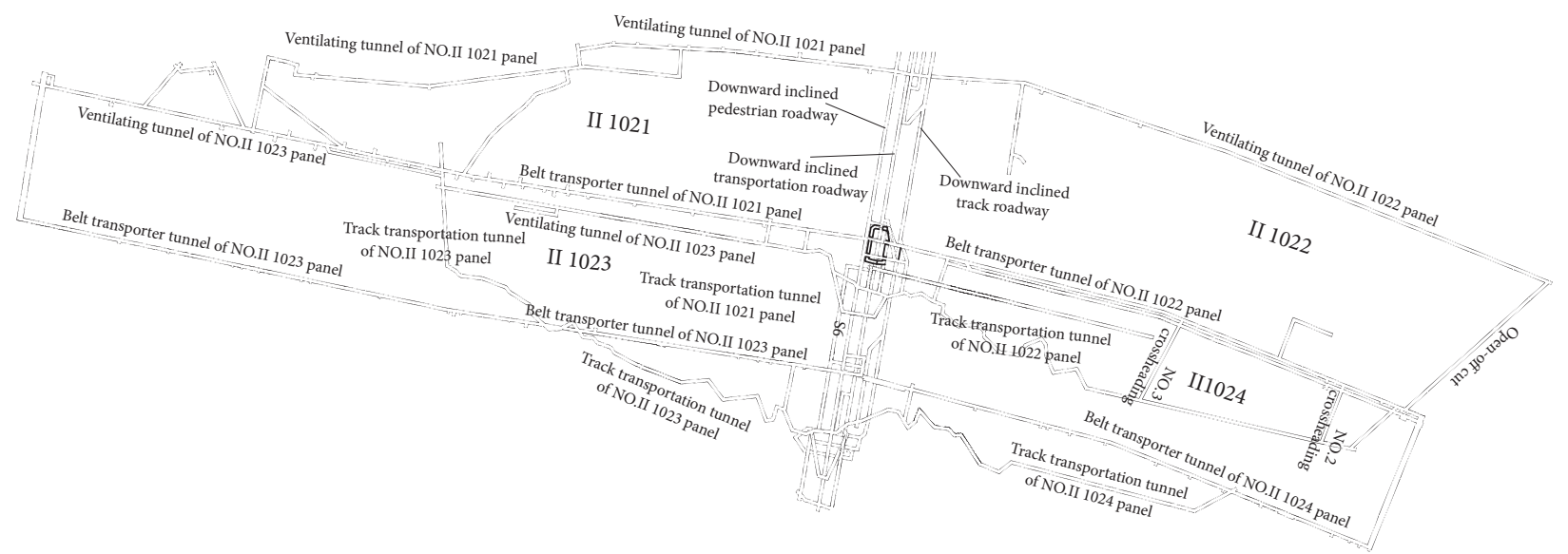

FIgure 3: General layout of the No. 2102 Mining Area.

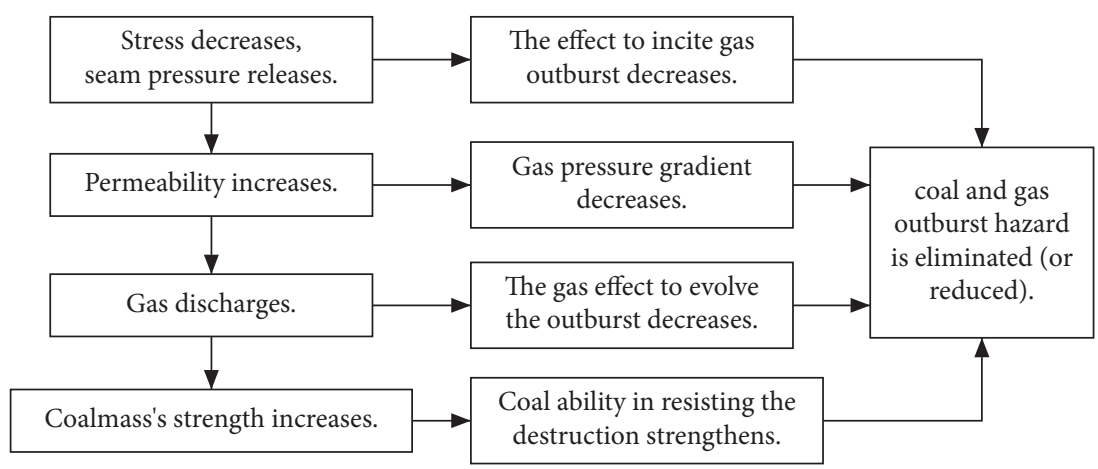

FIGURE 4: Outburst prevention principle with the protective seam mining.

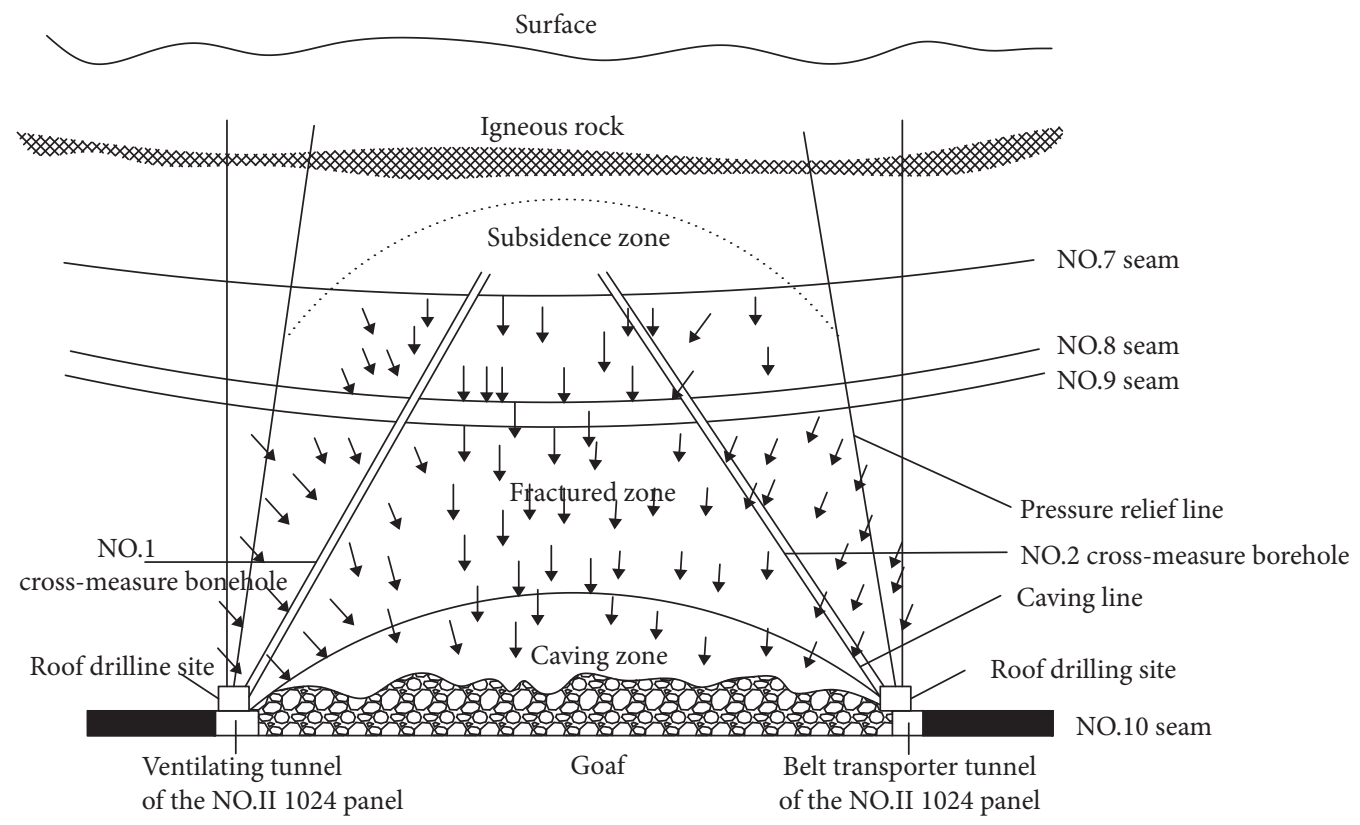

FIGURE 5: Diagram illustrating principle of gas emission in protected coal seam and gas drainage methods with cross-measure boreholes. 


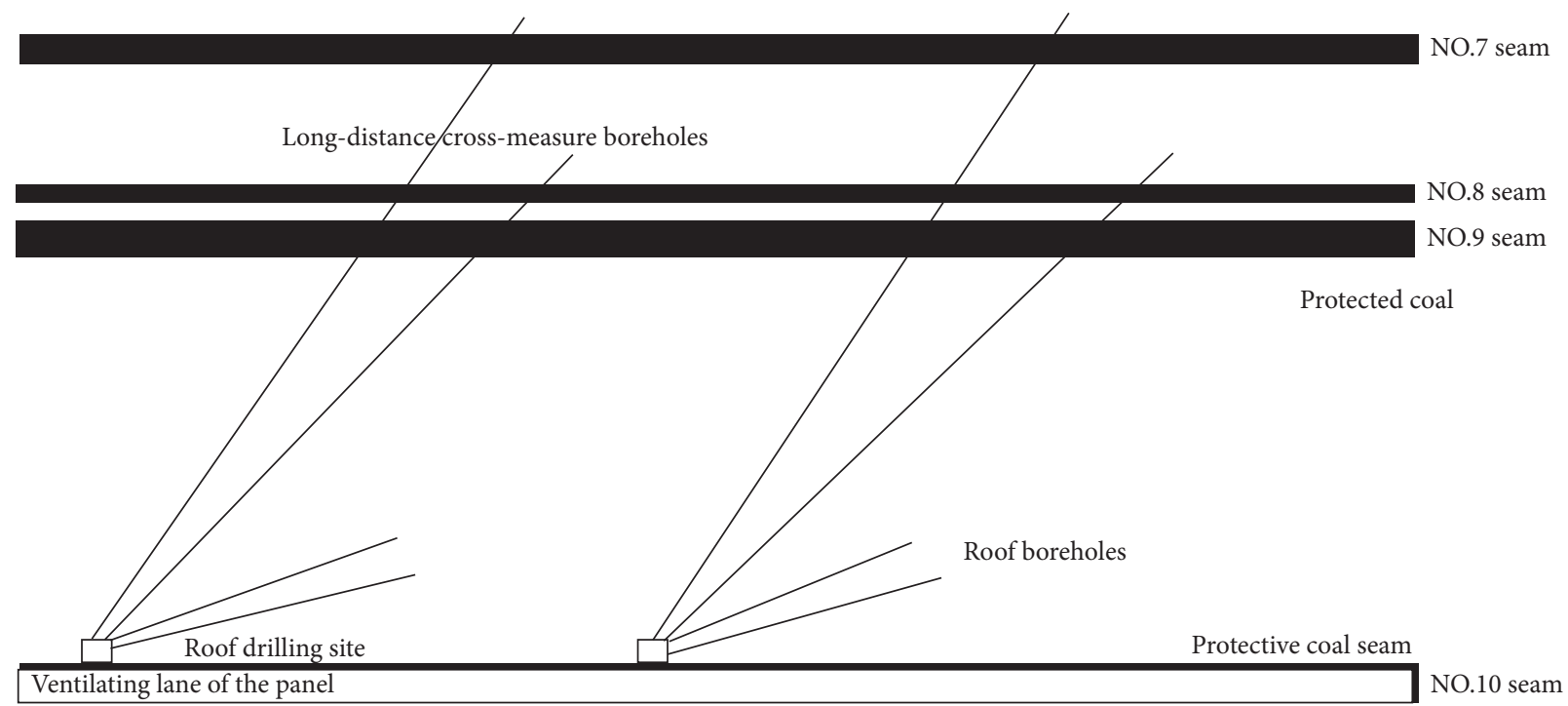

Figure 6: Cross section of the cross-measure boreholes in No. 21024 panel.

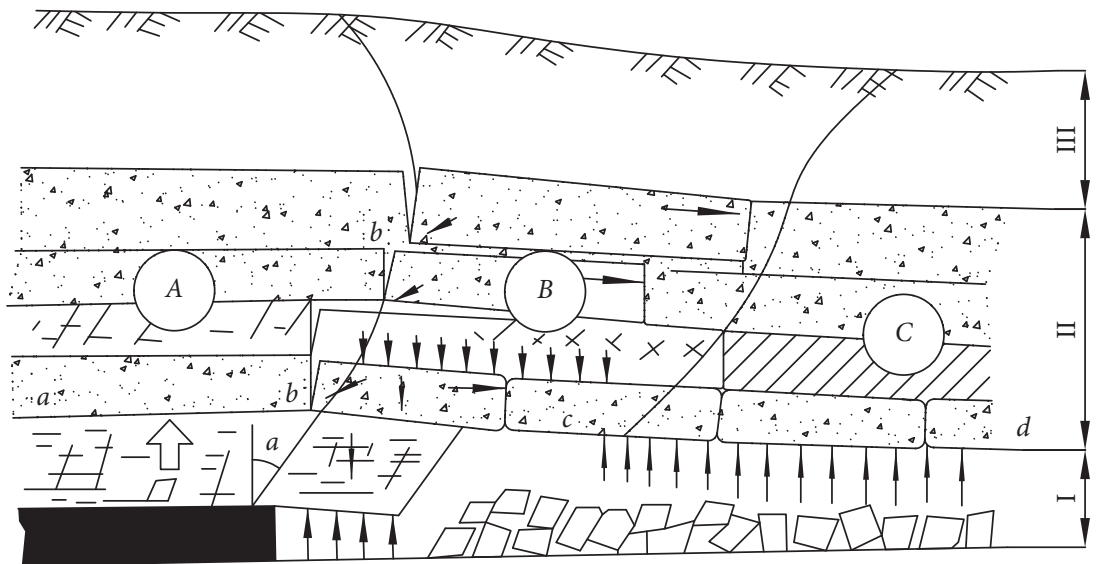

Figure 7: Subareas of overlying strata along advancing direction in mining panel. (A) Intact zone (a-b). (B) Separation zone (b-c). (C) Recompaction zone (c-d). (I) Caved zone. (II) Fractured zone. (III) Bending subsidence zone.The gas drainage method with surface wells is a major means of gas control in Haizi Coal Mine. First well is designed to be $100-150 \mathrm{~m}$ away from open-off cut and located in the middle of mining panel. Space between surface wells is $300 \mathrm{~m}$. Two surface wells are designed in No. 21024 panel. The schematic diagram of surface borehole's layout is shown in Figure 8.

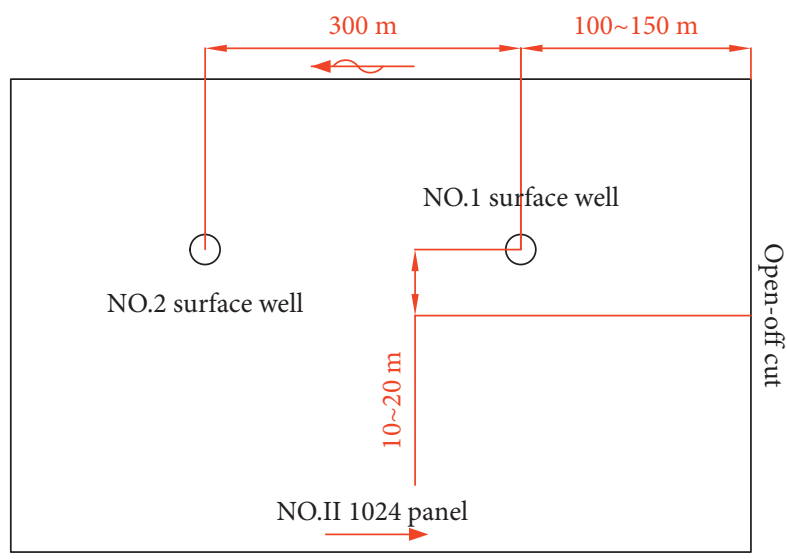

FIGURE 8: Schematic diagram of surface well's layout. 


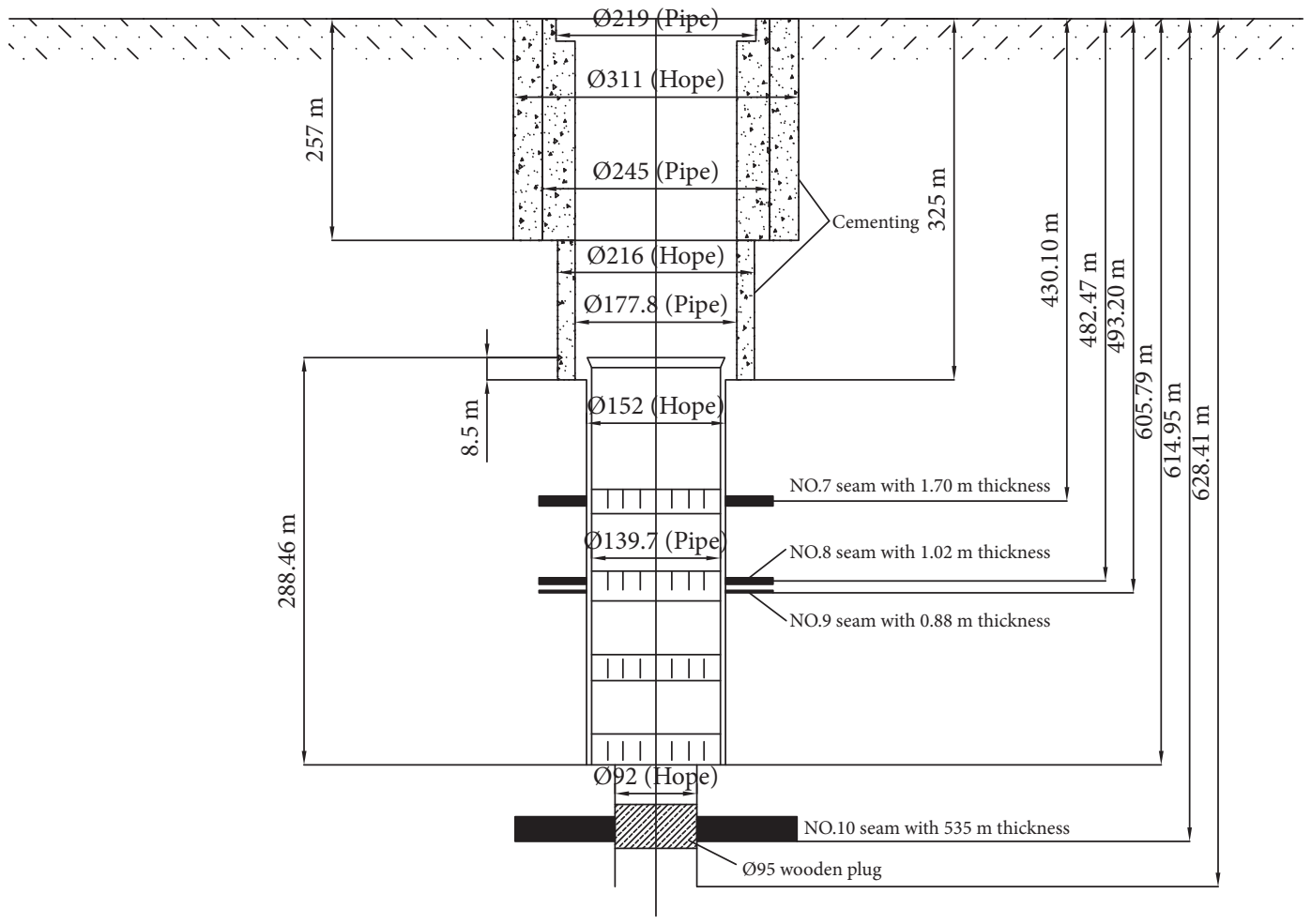

Figure 9: Schematic diagram of surface well's structure in No. 21024 panel.

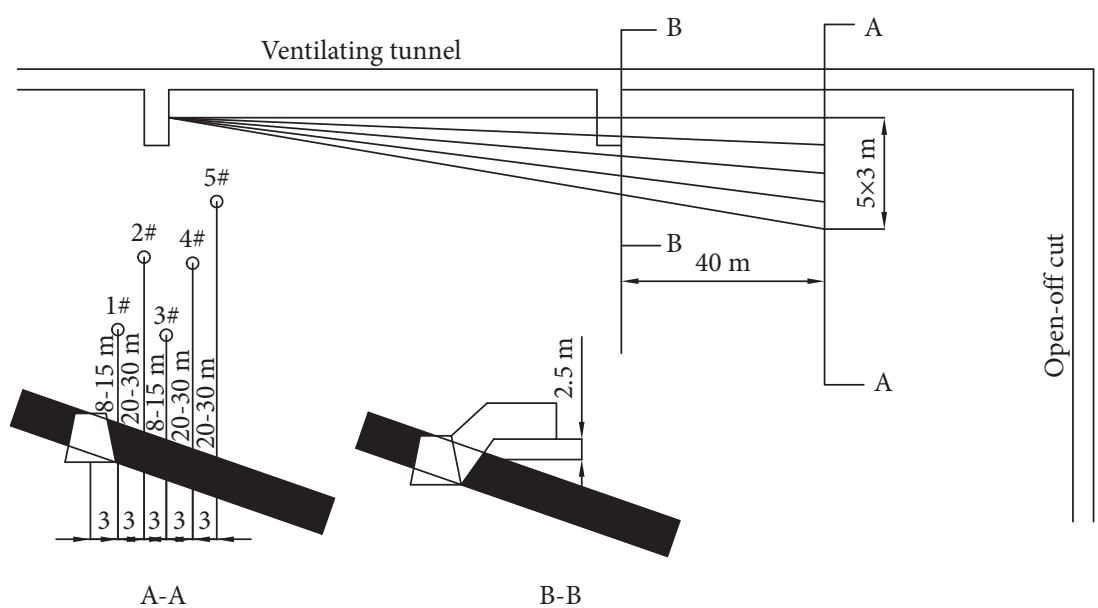

Figure 10: Roof borehole layout in No. 21024 panel.

In the case that roof gas drainage tunnels are closed, relative gas emission quantity is observed to increase in medium period of drainage but being relatively flat in other periods. Absolute gas emission quantity relatively reduces. Gas drainage quantity has no obvious change, but methane concentration decreases obviously in this case.

In the case that cross-measure boreholes being not used, both relative and absolute gas emission quantities do not obviously change. Gas drainage quantity of other drainage boreholes and methane concentration also experiences small change.
According to above analysis, effects of roof gas drainage tunnel and its accompanying boreholes on drainage performance in mining panel are limited. Methane concentration drops when they are closed. In comparison, crossmeasure borehole is the main measure to drain gas from No. 7 seam, No. 8 seam, and No. 9 seam because its gas drainage quantity is large. Therefore, it is determined to replace roof gas drainage tunnel and its accompanying boreholes with horizontal long roof boreholes.

Taking into account high excavation cost and low gas drainage quantity of roof gas drainage tunnel in the early 


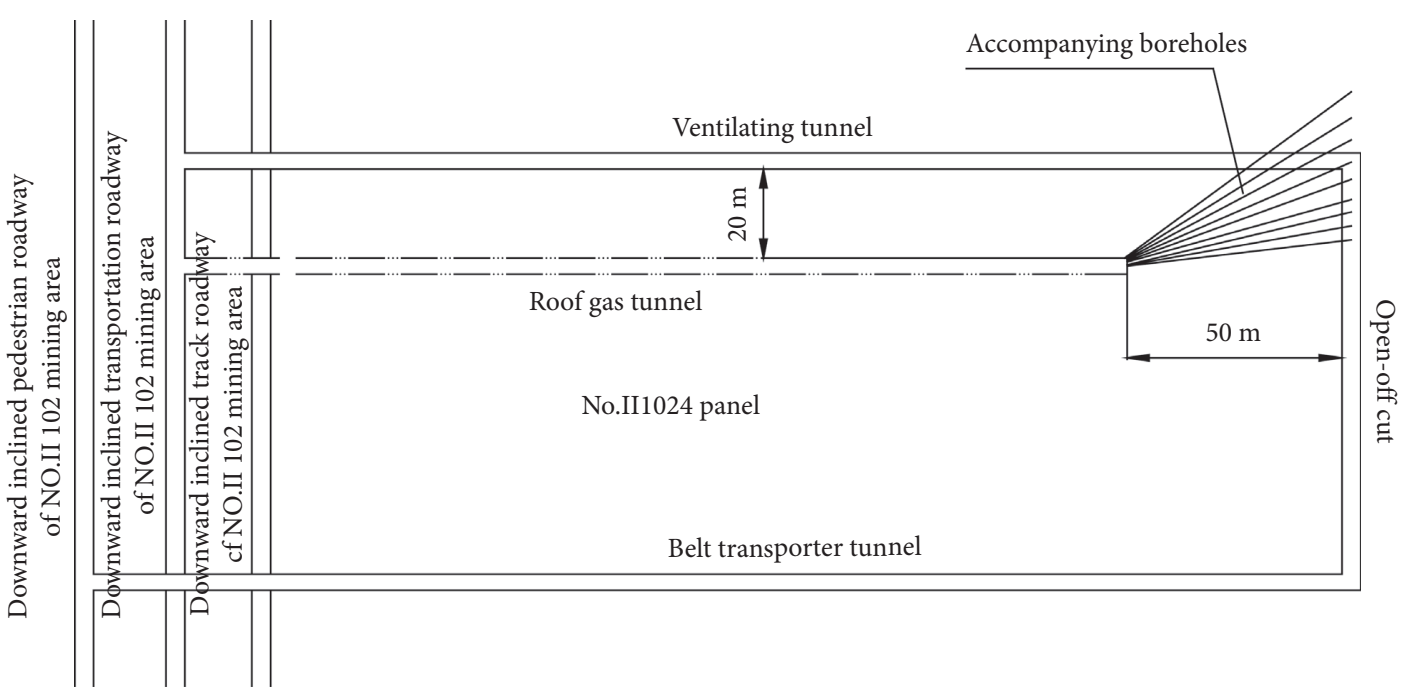

(a)

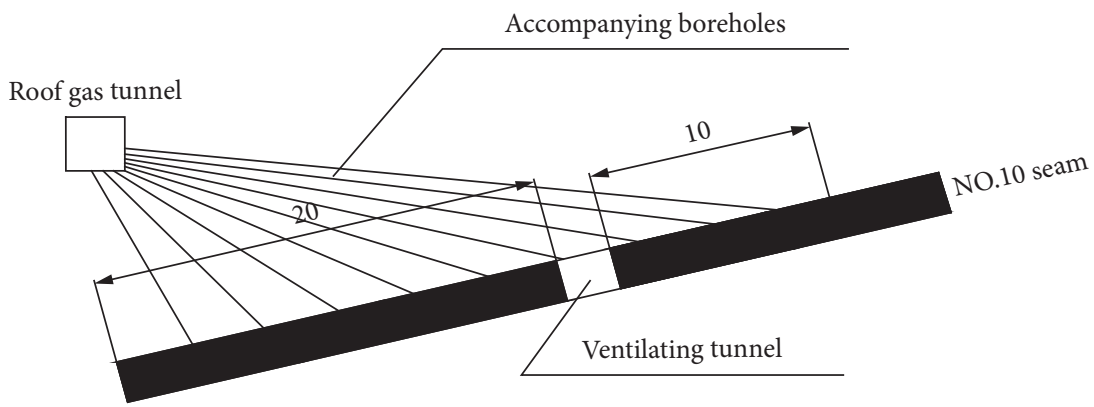

(b)

Figure 11: Roof gas drainage roadway and accompanying boreholes in No. 21024 panel: (a) plan view; (b) vertical cross section.

drainage stage, tests on horizontal long roof boreholes (replacing roof gas drainage tunnel) are carried out in No. 2 1023 panel, as shown in Figure 16. Boreholes are about $30 \mathrm{~m}$ distance from coal seam roof. They are parallel to ventilating lane and drilled in the direction of open-off cut. There are 6 boreholes in total, and their diameter is $108 \mathrm{~mm}$ while their length being $440 \mathrm{~m}$. Testing results show that gas drainage concentration is $15-90 \%$ and gas drainage quantity is stable at $8 \mathrm{~m}^{3} / \mathrm{min}$. Thus, drainage effect of horizontal long roof boreholes is good.

After implementing aforementioned optimized gas drainage measures, residual gas pressure of No. 7 seam, No. 8 seam, and No. 9 seam was measured. Firstly, the borehole should be well sealed:

(1) The sealing material includes piezometric tube, injection pipe, reflux pipe, cement, and polyurethane foam.

(2) Pressure test section of the piezometric tube is located at the top of borehole, and its front end is protected by steel mesh to prevent pipe plugging.

(3) Cement slurry and UEA expansion agent are used for borehole sealing. In order to completely seal the borehole, a certain amount of UEA expansion agent is added in the cement slurry, and the expansion of UEA is used to fill borehole space after solidification and contraction of cement slurry. The ratio of cement, UEA expansion agent, and water is $100: 8: 110$. The position of injection pipe is shown in Figure 17. First, the gap between piezometric tube, injection pipe, and borehole wall is sealed with polyurethane for about $1.5 \mathrm{~m}$, and then the injection pipe is used for pumping cement slurry until the slurry returns through reflux pipe.

(4) After 48 hours of solidification of slurry, pressure gauge is installed and pressure-measurement construction is completed.

The residual gas pressure in sealed borehole was measured by using pressure gauge. Results show that gas drainage efficiency of No. 7 seam, No. 8 seam, and No. 9 seam reached $58.64 \%$, resulting in a significant reduction of gas pressure to be below $0.74 \mathrm{MPa}$ (Figure 18). According to "Provisions for the Prevention and Control of Coal and Gas Outburst" in China, it is verified that the optimization of gas drainage scheme was effective. It has demonstrated that this optimization could effectively reduce gas emission and 


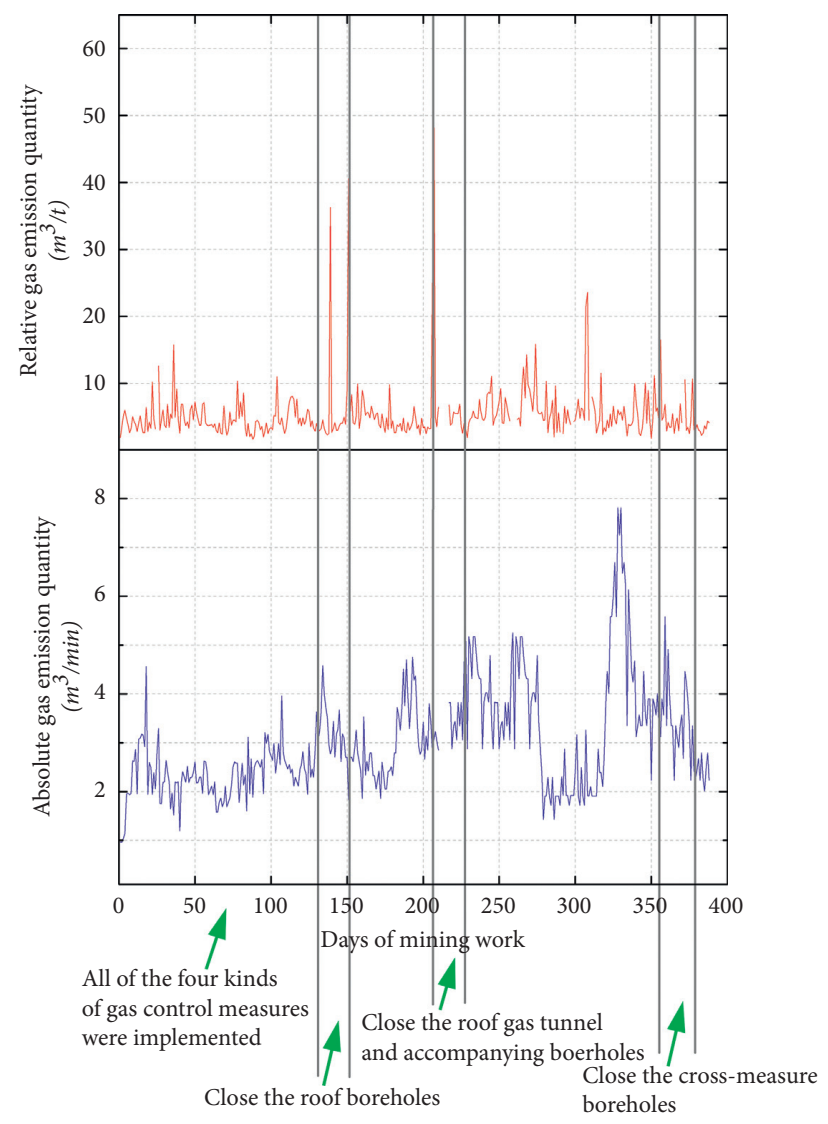

FIGURE 12: Variations of absolute and relative gas emission quantity during mining work when using different gas drainage measures in No. 21024 panel.

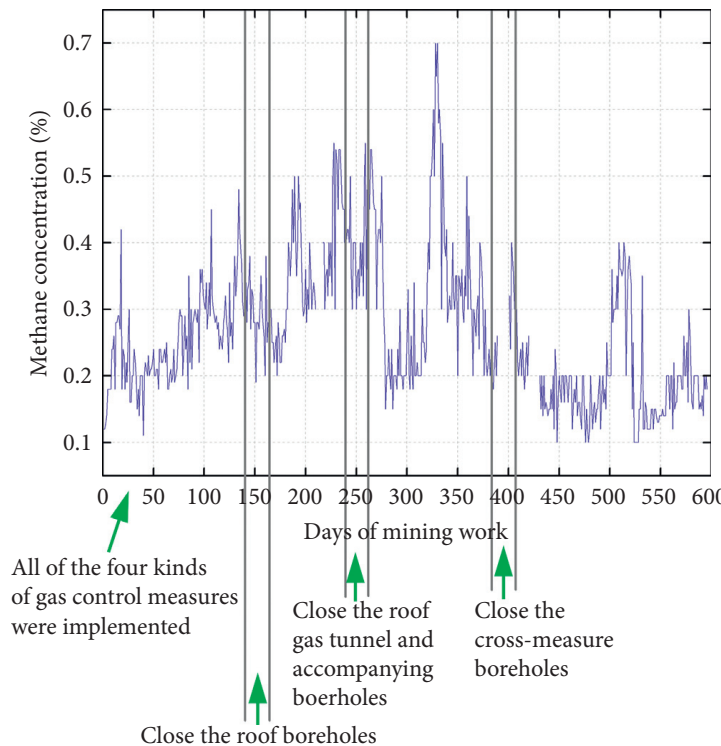

FIgURE 13: Variations of methane concentration in mining area when using different gas drainage measures in No. 21024 panel.

realize mining safety in the mining process of No. 10 seam. Furthermore, it can effectively reduce gas pressure and gas content of the protected seam (No. 7 seam, No. 8 seam, and
No. 9 seam) after No. 10 seam being mined, and it will be conducive to the safety production of No. 7 seam, No. 8 seam, and No.9 seam. 


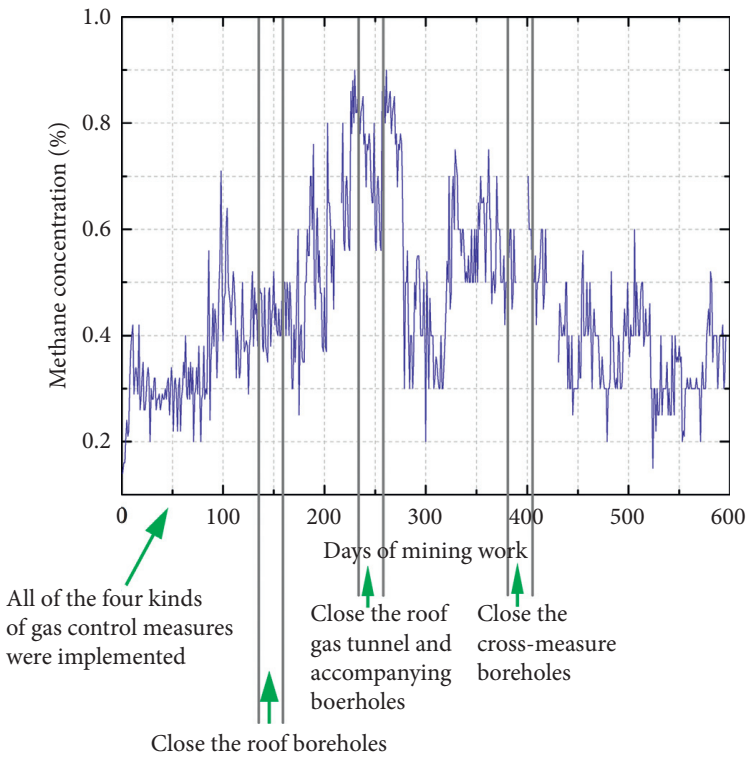

FIGURE 14: Variations of methane concentration when using different gas drainage measures in No. 21024 panel (particularly, at the corner of working face).

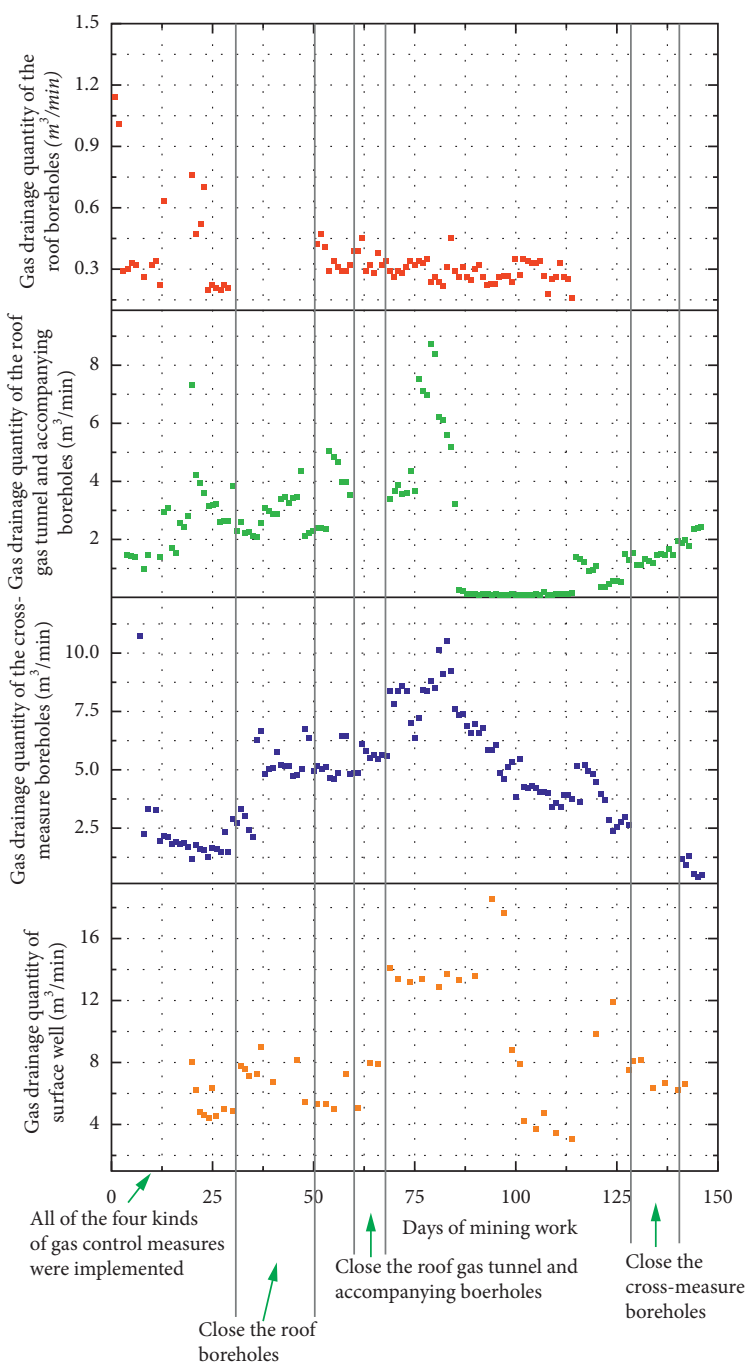

FIgURE 15: Variation of gas drainage quantity when using different gas drainage measures in No. 21024 panel. 


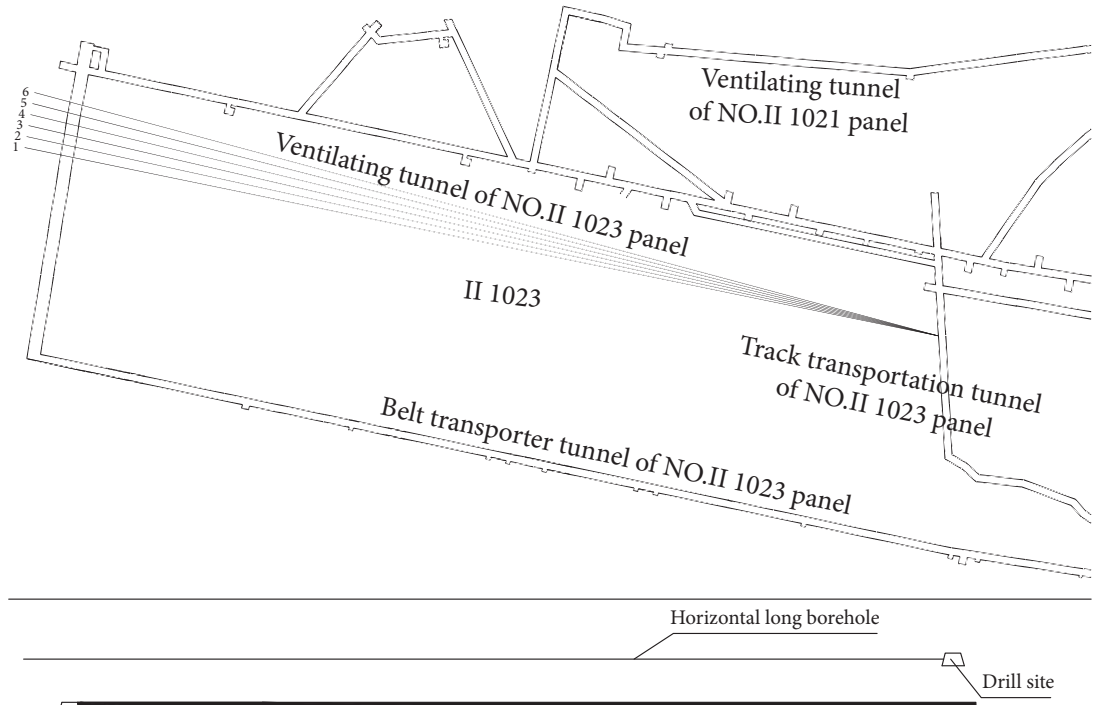

Open-off cut

Coal-mass

FIGURE 16: Schematic diagram of horizontal long borehole design in the roof.

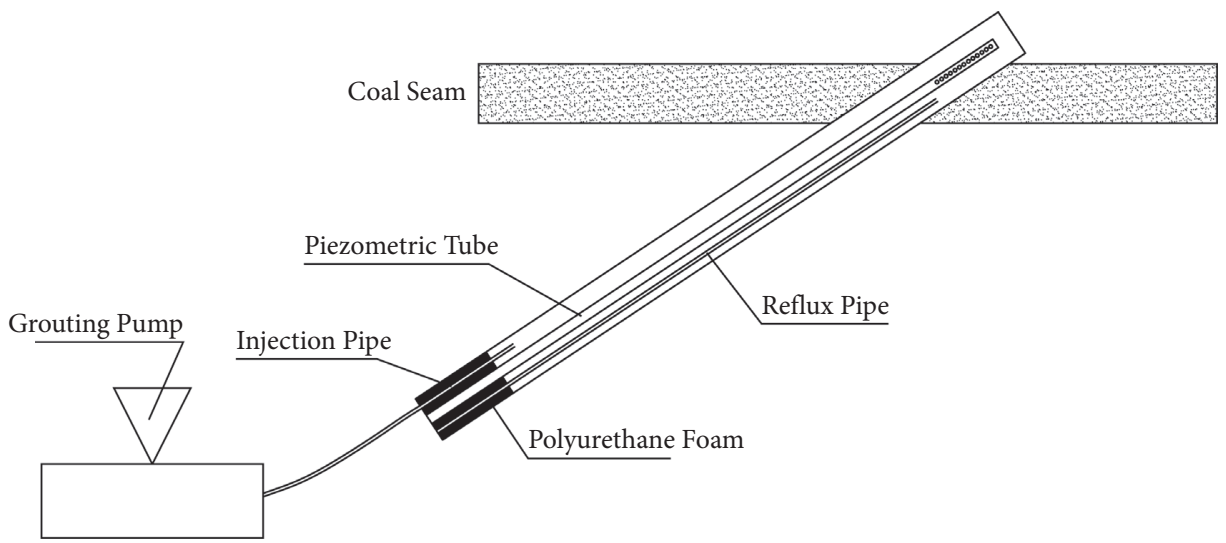

FIGURE 17: Schematic diagram of borehole sealing for measuring residual gas pressure.

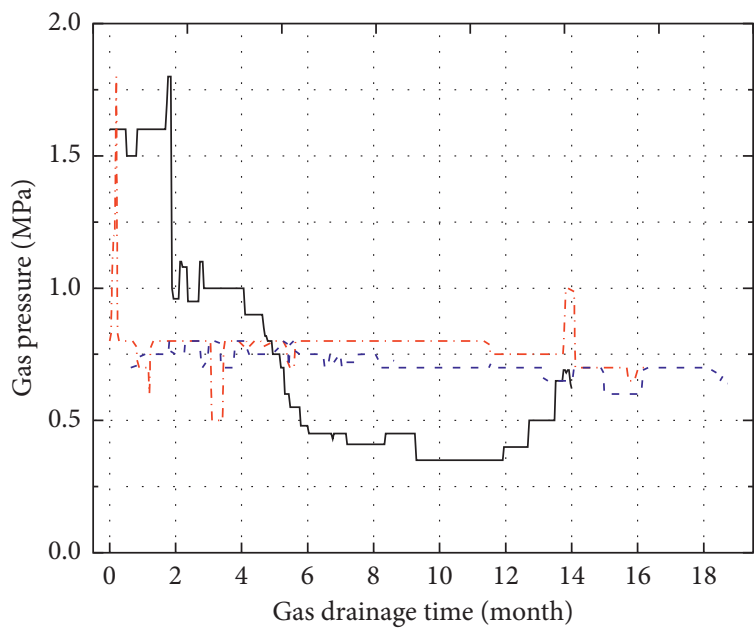

- Gas pressure of NO.7 coal seam

.... Gas pressure of NO.8 coal seam

- - - Gas pressure of NO.9 coal seam

Figure 18: Variations of gas pressure in No. 7, No. 8, and No. 9 coal seams. 


\section{Conclusions}

This study focuses on gas drainage design optimization in the mining process of No. 21024 panel for mining safety in Haizi Coal Mine. Four gas drainage measures are discussed for gas control, i.e., cross-measure boreholes into overlying seams, surface goaf wells, roof boreholes, and gas drainage roof roadway. Optimization on combinations of above measures is conducted and following conclusions could be obtained: drainage performance of roof gas drainage roadway with accompanying boreholes is poor. It could be replaced by horizontal long roof boreholes as the latter shows better drainage outcomes and could achieve safe mining and low costs. In No. 21023 panel, when adopting roof boreholes (replacing roof gas drainage roadway), gas drainage concentration ranges from $15 \%$ to $90 \%$, when the drainage quantity being stable at $8 \mathrm{~m}^{3} / \mathrm{min}$. Furthermore, after implementing optimized combination of gas drainage measures, the drainage efficiency of No. 7 seam, No. 8 seam, and No. 9 seam increases to $58.64 \%$, resulting in a significant reduction of gas pressure to be below $0.74 \mathrm{MPa}$.

Outcomes of this study could help eliminating risk of coal and gas outburst in upper far-distance protected coal seams (No. 7 seam, No. 8 seam, and No. 9 seam) through optimization of gas drainage design in the mining process of the lower protective coal seam (No. 10 seam). For other coal mines that have similar geological conditions with Haizi Coal Mine, it is expected to deliver some guidance on their gas drainage design, for enhancing gas drainage performance and ensuring mining safety.

\section{Data Availability}

The data used for conducting classifications are available from the corresponding author authors upon request.

\section{Conflicts of Interest}

The author(s) declare that there are no conflicts of interest with respect to the research, authorship, and/or publication of this article.

\section{Acknowledgments}

This study was financially supported by the University Synergy Innovation Program of Anhui Province (No. GXXT-2021-018), National Natural Science Foundation of China (Nos. 51904013 and 51934007), Institute of Energy, Hefei Comprehensive National Science Center (No. 21KZS218), Youth Science and Technology Talents Support Program (2020) by Anhui Association for Science and Technology (No. RCTJ202005), Open Research Fund of State Key Laboratory of Coal Resources and Safe Mining, CUMT (No. SKLCRSM20KF003), and Anhui Oversea Returnees Innovation Project Funding (No. 2019LCX001).

\section{References}

[1] M. M. Wu and Y. Zhong, "Statistics analysis of our country's coal mine fatal accidents from 2012 to 2013," Coal Technology, vol. 10, pp. 296-299, 2014.

[2] B. Q. Lin and J. G. Zhang, Theory and Technology about Gas Drainage in the Coal Mine, China Mining University Press, Xuzhou, China, 1995.

[3] D. Deb, "Analysis of coal mine roof fall rate using fuzzy reasoning techniques," International Journal of Rock Mechanics and Mining Sciences, vol. 40, no. 2, pp. 251-257, 2003.

[4] S. Kong, P. Yang, X. Fang et al., "Analysis of characteristics of safety accidents in university laboratory and research on the causes of accidents," E3S Web of Conferences, vol. 257, Article ID 03050, 2021.

[5] X. Tong, H. Wen, X. Cheng et al., "Characteristics of pressure relief gas extraction in the protected layer by surface drilling in huainan," Advances in Civil Engineering, vol. 2021, Article ID 9966843, 11 pages, 2021.

[6] L. Y. Qing, "Gas control mode of outburst coal seams in huainan coal mining area," Coal Technology, vol. 35, 2016.

[7] C. Guo and L. Wenke, "On comprehensive gas control technology in mining of protective layer in linhuan coal mine," Mineral Engineering Research, vol. 32, 2017.

[8] W. Xudong and Y. Xing, "Gas drainage effect and parameter optimization of long borehole along roof strike based on cfd numerical simulation," Mining Safety \& Environmental Protection, vol. 46, 2019.

[9] H. Zhang, "Application of coal seam gas drainage technology with advanced pressure-relief in gas control of Xingyu coal mine," Shanxi Chemical Industry, vol. 38, 2018.

[10] Z. Wang, Y. Sun, Y. Wang, J. Zhang, and Z. Sun, “A coupled model of air leakage in gas drainage and an active support sealing method for improving drainage performance," Fuel, vol. 237, pp. 1217-1227, 2019.

[11] X. Wu, "Application and analysis of mined-out area high gas drainage drilling technology," Mechanical Management and Development, vol. 31, 2016.

[12] H. Y. Ma, Z. F. Wang, and H. M. Yang, "Study on effective drainage radius of downward borehole drilled through strata in sijiazhuang mine," Coal Engineering, vol. 5, 2011.

[13] L. Sheng, "Study on high level gas drainage gateway layout along roof strike in high gassy mechanized coal mining face," Coal Science and Technology, vol. 45, 2017.

[14] H. Wang, Y. Cheng, and L. Yuan, "Gas outburst disasters and the mining technology of key protective seam in coal seam group in the Huainan coalfield," Natural Hazards, vol. 67, no. 2, pp. 763-782, 2013.

[15] G. L. Dai, "Forecast of the gas effused from the face in protective seam," Journal of China Coal Society, vol. 32, pp. 382-385, 2007.

[16] V. Leisle and R. Kovalski, "Assessing the well yield during methane drainage in coal mines," Ecology Environment and Conservation, vol. 23, 2017.

[17] W. Zhang, "Numerical simulation on stress evolution and deformation of overlying coal seam in lower protective layer mining," Alexandria Engineering Journal, vol. 59, pp. 3623$3633,2020$.

[18] Q. Dong and Hong, "Study on numerical simulation of pressure-relief law of coal-rock masses and gas in outburst coal seams under thick key stratum," Zhongzhou Coal, vol. 7, 2015.

[19] H. Yang and W. Qiu, "Numerical simulation research on mining stress field of overlying coal-rock seam under far 
distance lower protective seam mining," Industry and Mine Automation, vol. 43, 2017.

[20] W. Sun and S. Wu, "A study of crack initiation and source mechanism in the Brazilian test based on moment tensor," Engineering Fracture Mechanics, vol. 246, no. 4, Article ID 107622, 2021.

[21] D. Huang, "A numerical simulation method for time-dependent growth of cracks in rocks and its validation," Chinese Journal of Rock Mechanics and Engineering, vol. 36, pp. 1623-1633, 2017.

[22] M. V. Bastawrous and M. I. Hussein, "Closed-form existence conditions for band-gap resonances in a finite periodic chain under general boundary conditions," 2021, https://arxiv.org/ abs/2108.00828.

[23] B. Huo, Y. Tai, X. Meng, and T. Kuang, "Deformation and failure mechanism of full seam chamber with extra-large section and its control technology," Open Geosciences, vol. 12, no. 1, pp. 390-405, 2020. 